\title{
CARBON PASTE ELECTRODE HEXADECYLTRIMETHYLAMMONIUM BROMIDE MODIFIED NATURAL ZEOLITE FOR CHROMIUM(VI) DETECTION
}

\author{
Budi Riza Putra ${ }^{1}$, Latifah K Darusman ${ }^{1.2, *}$, and Eti Rohaeti ${ }^{1}$ \\ ${ }^{1}$ Division of Analytical Chemistry, Department of Chemistry, Faculty of Mathematics and Natural Sciences, \\ Bogor Agricultural University, Kampus IPB Darmaga, Bogor 16680, Indonesia \\ ${ }^{2}$ Biopharmaca Research Center, Institute of Research and Community Empowerment, \\ Bogor Agricultural University, Kampus IPB Taman Kencana, Bogor 16151, Indonesia
}

Received February 15, 2013; Accepted June 12, 2013

\begin{abstract}
A simple voltammetric technique for quantification of chromium(VI) is presented in this work. The technique is based on linear sweep voltammetric reduction $\mathrm{Cr}(\mathrm{VI})$ on hexadecyltrimethylammonium bromide (HDTMABr) modified Lampung zeolite carbon paste electrode. Selected HDTMABr concentration for natural zeolite modification is obtained $200 \mathrm{mM}$. Working electrode for chromium(VI) detection is made by graphite, paraffin oil and $\mathrm{HDTMABr}$ modified Lampung zeolite. The effect of supporting electrolyte matrix, $\mathrm{pH}$ and also scan rate is also investigated. The calibration curve for chromium(VI) detection using the proposed method shows linearity from 0.2 to $1.0 \mathrm{mM}$ with sensitivity, detection and quantification limit, and precision was $0.4294 \mathrm{mM}, 3.63 \times 10^{-4} \mathrm{mM}, 1.197 \times 10^{-3} \mathrm{mM}, 4.49 \%$, respectively.
\end{abstract}

Keywords: Lampung clinoptilolite zeolite; chromium(VI); HDTMABr modified zeolite carbon paste electrode; linear sweep voltammetry; heavy metal

\section{ABSTRAK}

Teknik voltametri sederhana untuk kuantifikasi kromium(VI) ditampilkan dalam penelitian ini. Teknik didasarkan pada voltametri sapuan linear reduksi Cr(VI) pada elektrode pasta karbon zeolit klinoptilolit Lampung termodifikasi heksadesiltrimetilamonium bromida (HDTMABr). Konsentrasi HDTMABr terpilih untuk modifikasi zeolit alam yang diperoleh adalah $200 \mathrm{mM}$. Elektrode kerja untuk deteksi kromium(VI) dibuat dari campuran grafit, minyak parafin, dan zeolit Lampung termodifikasi HDTMABr. Pengaruh matriks elektrolit pendukung, $\mathrm{pH}$, dan laju selusur juga dipelajari. Kurva kalibrasi untuk deteksi kromium(VI) menggunakan metode yang diusulkan menunjukkan linearitas dari 0,2 sampai 1,0 mM dengan sensitivitas, limit deteksi, limit kuantisasi, dan ketelitian berturut-turut adalah 0,4294 $\mathrm{mM}, 3,63 \times 10^{-4} \mathrm{mM}, 1,197 \times 10^{-3} \mathrm{mM}, 4,49 \%$.

Kata Kunci: zeolit klinoptilolit Lampung; kromium(VI); elektrode pasta karbon zeolit termodifikasi HDTMABr; voltametri sapuan linear; logam berat

\section{INTRODUCTION}

Chromium is a metallic element that exists primarily in the mineral chromite, mainly present in waters, soils, flora and fauna, rocks, volcanic dust and gases. The occurrence of chromium in the environment is primarily as a result of human activities through production of waste water in metal smelting, metallurgy, tanning, electroplating, and dyestuff industries [1-2].

The two most abundant forms and most thermodynamically stable oxidation states of chromium in the environment are $\mathrm{Cr}(\mathrm{III})$ and $\mathrm{Cr}(\mathrm{VI})$ and the toxicity of chromium mainly depends on its oxidation state [3]. It is usually assumed that $\mathrm{Cr}(\mathrm{VI})$ is about $100-1000$ times more toxic than $\mathrm{Cr}(\mathrm{III})$ [4]. Therefore, determination of
$\mathrm{Cr}(\mathrm{VI})$ is more important than $\mathrm{Cr}(\mathrm{III})$ and design of analytical method which is capable of selective measurement of chromium $(\mathrm{VI})$ is of great importance [1]. $\mathrm{Cr}(\mathrm{VI})$ which depending on the $\mathrm{pH}$, is available as $\mathrm{CrO}_{4}{ }^{2-}, \mathrm{HCrO}_{4}^{-}, \mathrm{H}_{2} \mathrm{CrO}_{4}$ or $\mathrm{Cr}_{2} \mathrm{O}_{7}{ }^{2-}$ is toxic, mutagenic, and carcinogenic [1].

Analysis of $\mathrm{Cr}(\mathrm{VI})$ in environmental samples is routinely carried out using analytical techniques, such as spectrophotometry [5], inductively coupled plasmaatomic emission spectrometry [6], atomic absorption spectrometry [7], high pressure liquid chromatography [8], X-ray fluorescence [9], and mass spectrometry [10]. However, these techniques always need extensive labor and analytical resources, which prohibit their use for rapid detection and field deployment [11].

* Corresponding author. Tel/Fax : +62-251-8628766/8624567

Email address : latifah.kd@gmail.com 
Comparing to the analytical methods mentioned above, electrochemical techniques are very attractive for $\mathrm{Cr}(\mathrm{VI})$ analysis, owing to their high sensitivity, inherent simplicity, good selectivity and low cost [11]. There are various electroanalytical techniques have been used for determination of $\mathrm{Cr}(\mathrm{VI})$. Some of the most widely utilized electrode materials used for chromium determination and speciation studies are mercury based electrodes such as hanging mercury drop electrodes and mercury film electrodes whose potential toxicity and operation limitations discouraged its usage in analytical practice $[3,11]$. Solid electrodes, such as glassy carbon [12], carbon paste [2], gold [13], CTAB modified carbon paste electrode [14] have been widely used for $\operatorname{Cr}(\mathrm{VI})$ detection.

Zeolite is the most abundant of their natural category are crystalline microporous aluminosilicates with well-defined structures that consists of a framework formed by tetrahedra of $\mathrm{SiO}_{4}$ and $\mathrm{AlO}_{4}$. The isomorphous substitution of $\mathrm{Al}^{3+}$ for $\mathrm{Si}^{4+}$ in the tetrahedra results in a negative charge on the zeolite framework that can be balanced by exchangeable cations. Therefore, zeolites can exchange cations but not anions. It has been demonstrated that the cationic surfactants have a great affinity to this negative charge. This property has been used to modify the external surface of zeolite by adsorbing a cationic surfactant to improve the anionic exchange capacity [15]. The cationic surfactants that are most commonly used to modify zeolites are usually long alkyl chains with a quarternary ammonium group at one end of the chain such as hexadecyltrimethylammonium (HDTMA) bromide [16]. The sorption of a cationic surfactant on external surface of a zeolite can be governed mainly by cationic exchange and hydrophobic interactions [17]. At low surfactant loading, the surfactant cations are exchanged with exchangeable cations of the zeolite until a monolayer of surfactant cations is formed at the external surface. At concentrations greater than critical micelle concentration (CMC), bilayer surfactant molecules (admicelle) is attached to external surface, where the outer layer of surfactant molecules is bound by hydrophobic interactions [18]. In this case a surfactant modified zeolite (SMZ) has produced with changing the external surface of the zeolite from negative into positive which now displays anion exchange capacity.

The carbon-paste electrode (CPE) was first introduced by Ralph N Adams in 1958 [19]. CPE and zeolite-modified carbon paste electrode (ZMCPEs) are widely used in various field of electrochemistry [20-21]. In comparison with ion-selective electrode based on polymeric membranes, ZMCPEs possess advantages such as ease of preparation and regeneration, stable response and very low Ohmic resistance [22]. These focus research have been extensively reviewed by Walcarius [23].

In this work, a natural abundant zeolite material originated from Lampung area was pretreated with 3 different conditions by physical $\left(200{ }^{\circ} \mathrm{C}\right)$ and chemical (acid and alkaline). Cation exchange capacity (CEC) values of zeolite before and after treatment were compared and selected zeolite has the highest CEC value. Then natural zeolite was modified by HDTMA cation with different concentrations and selected SMZ has highest the adsorption capacity (Q) value. Chromate anion exchange capacity was performed to selected SMZ and characterized with FTIR. The resulted SMZ was used for modification of carbonpaste electrode (SMZ-CPE). The obtained electrode was used to determine $\mathrm{Cr}(\mathrm{VI})$ with voltammetry techniques.

\section{EXPERIMENTAL SECTION}

\section{Materials}

All chemicals with pro analysis grade were purchased from E. Merck and used as received without purification. Natural clinoptilolite zeolite as the object of the study was obtained from Lampung Province.

\section{Instrumentation}

The zeolites were characterized by scanning microscope electron (SEM JEOL JSM-6510). Voltammetric measurements were carried out using eDAQ Advanced Electrochemistry System ERZ101. A single compartment cell was used for electrochemical measurements. An $\mathrm{Ag} / \mathrm{AgCl}$ (saturated $\mathrm{KCl}$ ) and $\mathrm{Pt}$ wire electrode were used as the reference and counter electrodes, respectively. All measurements were performed at room temperature.

\section{Procedure}

\section{Preparation and characterization of natural zeolite and SMZ}

The natural zeolite used in this study originated from Lampung. It was crushed and pulverized in mortar and sieved to a particle size 200 mesh. The powder was activated each with $1 \mathrm{M} \mathrm{HCl}, \mathrm{NaOH}$, and temperature $200{ }^{\circ} \mathrm{C}$ for several hours. The CEC of zeolite was determined by the method of Klute [24]. The external surface of zeolite was modified by adsorbing the cationic surfactant HDTMA-Br through similar procedures [25] with several modifications. In brief, the procedure was as follows: $2.5 \mathrm{~g}$ of activated zeolite was added to bottles $10 \mathrm{~mL}$ containing $0.1,1$, 10, 100, and $200 \mathrm{mM}$ HDTMA-Br solutions and the 
suspensions were shaken at room temperature for $24 \mathrm{~h}$ then was left for $48 \mathrm{~h}$. The mixture was then centrifuged and the solid was washed with water in order to remove unreacted monomers. Finally, the material was air dried. Hereafter, the organo-zeolite is abbreviated as SMZ.

Non-adsorbed HDTMA-Br in the filtrate were determined by spectrophotometric method using Bromophenol Blue (BPB) solution [26]. An experiment to determine optimum chromate anion concentration exchanged method by SMZ based on previously reported method [26].

\section{Preparation of HDTMABr modified zeolite carbon paste electrode (SMZ-CPE)}

The SMZ-CPE was prepared at different ratios of HDTMABr modified zeolite/graphite fine powder/paraffin oil: 1:69:30, 2.5:67.5:30, 5:6.5:30, 7.5:62.5:30, 10:60:30 $\%(w / w)$ by hand-mixing of HDTMABr modified zeolite with graphite fine powder and paraffin oil. The carbon paste was packed firmly into hole of the electrode body (glass cylindrical tube, i.d. $3 \mathrm{~mm}$ ). The electrical contact was established with a copper wire. The surface of the SMZ-CPE was then smoothed and polished on a weighing paper.

The supporting electrolyte $\mathrm{HNO}_{3} \quad 0.3 \mathrm{M}$ [3] was placed in the voltammetric cell with SMZ-CPE, Ag/AgCl (saturated $\mathrm{KCl}$ ) and $\mathrm{Pt}$ wire electrode were used as working, reference, and counter electrodes, respectively. These 3 electrodes were immersed into the measuring solution and potential was scanned from -0.5 to $1.0 \mathrm{~V}$ vs $\mathrm{Ag} / \mathrm{AgCl}$ using cyclic voltammetry. The peak current was appeared at a potential $\sim 0.2 \mathrm{~V}$ vs $\mathrm{Ag} / \mathrm{AgCl}$. All electrochemical measurements were conducted at a room temperature. The electrodes were kept in open air when not in use. A series of optimization studies were made on linear sweep voltammetric parameters; optimized values of the parameters were: initial E: $500 \mathrm{mV}$, final E: $-1000 \mathrm{mV}$, pulse width: $80 \mathrm{~ms}$, pulse height: $2 \mathrm{mV}$, step period: $10 \mathrm{~ms}$, and rest time: $2 \mathrm{~s}$. Scan rate was varied by changing either step potential or pulse width.

\section{RESULT AND DISCUSSION}

\section{Activation of Zeolite}

Unlike synthetic zeolite structure can be predicted from its constituent compounds, natural zeolite has irregular structure depending on the conditions of its formation in nature. Therefore, use of natural zeolite as adsorbent required activation process. The activation process is necessary to remove specific ion from the structure of zeolite and locate more easily removable ones prior to any application of it for ion exchange purposes. In practice, the result of any activation is the increase of zeolite content in a single cation, i.e. to bring the material to near homoionic form. The final homoionic or near homoionic state of the zeolite was found to improve their effective exchange capacity and performance in ion exchange applications [27].

CEC value of Lampung zeolite was obtained with different activation treatments. H-zeolite is a product of acid treatment and its CEC value $(25.5 \mathrm{meq} / 100 \mathrm{~g})$ decreased to 0.4 times smaller than original zeolite $(42.40 \mathrm{meq} / 100 \mathrm{~g})$. Acid treatment on natural zeolite not only removes impurities that block the pores of zeolite such as metal oxides compounds but also progressively eliminate cations and finally dealuminate the structure as the strength and duration of treatment increases [28]. Dealumination leads to the breaking of $\mathrm{Al}-\mathrm{O}$ bonds, as well as a loss of crystallinity, particularly at low Si/Al ratios [29]. Thus, the negative charge on zeolite surface become reduced consequently the amount of exchangeable cations in zeolite become fewer.

Thermal process for zeolite activation aims to eliminate water molecules and organic substances impurities that exist in pores and framework zeolite. Dehydration and thermal treatment can also lead to cation migration, thereby influencing cation location and pore openings and ultimately will affect the equilibrium and kinetics of adsorption [28]. CEC value obtained thermal activation of zeolite $(54.7 \mathrm{meq} / 100 \mathrm{~g})$ showed an increasing was only about 1.3 times. It was indicated that natural zeolite contained little water vapor and volatile organic compounds that embedded on surface and pores of zeolite.

Zeolites with $\mathrm{NaOH}$ treatment produces $\mathrm{Na}$ zeolite $(107.50 \mathrm{meq} / 100 \mathrm{~g})$ and gives the highest CEC value, approximately 2.5 times than original zeolite. Zeolite with $\mathrm{NaOH}$ treatment will result dissolution process of silica which is one of main component in the zeolite framework [30]. Dissolved silica will cause changes in zeolite structure and silica reduction in the zeolite framework so that Si/Al ratio also decreased. It would result in increasing adsorption capacity and zeolite selectivity for polar molecules such as water vapor [31]. In addition to lowering Si/Al ratio, treatment of natural zeolite with $\mathrm{NaOH}$ also resulted in the loss of certain ions in the zeolite framework and replaced by $\mathrm{Na}^{+}$ions so that natural zeolite had near homoionic form [27]. This Na-form zeolite was expected had same relative pore size that will support when hexadecyltrimethylammonium bromide (HDTMABr) surfactant modified zeolite surface because positively charged hydrophilic head group will exchange charge primarily with $\mathrm{Na}^{+}$ions. Therefore, Na-form zeolite of Lampung was selected because adsorption capacity and selectivity of zeolite towards $\mathrm{HDTMABr}$ also would 

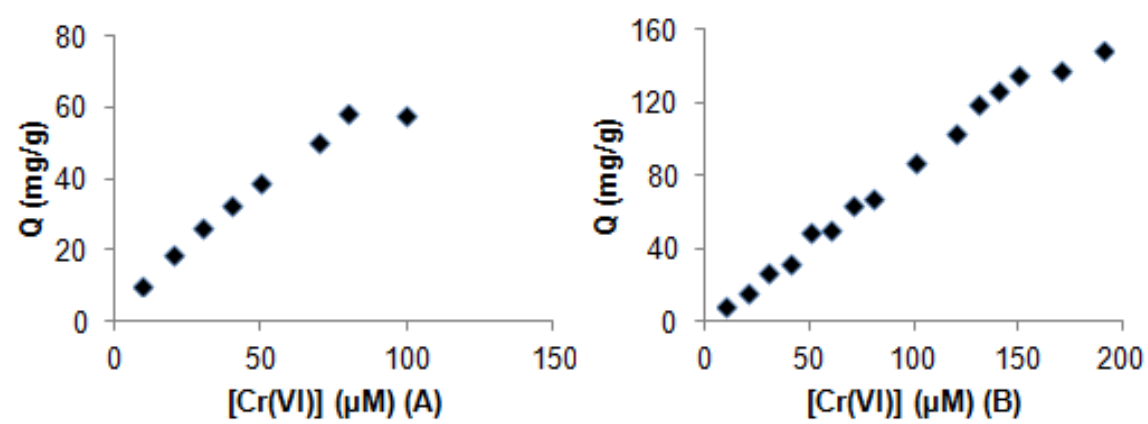

Fig 1. Chromate anion-exchange on (A) natural zeolite and (B) HDTMABr modified zeolite
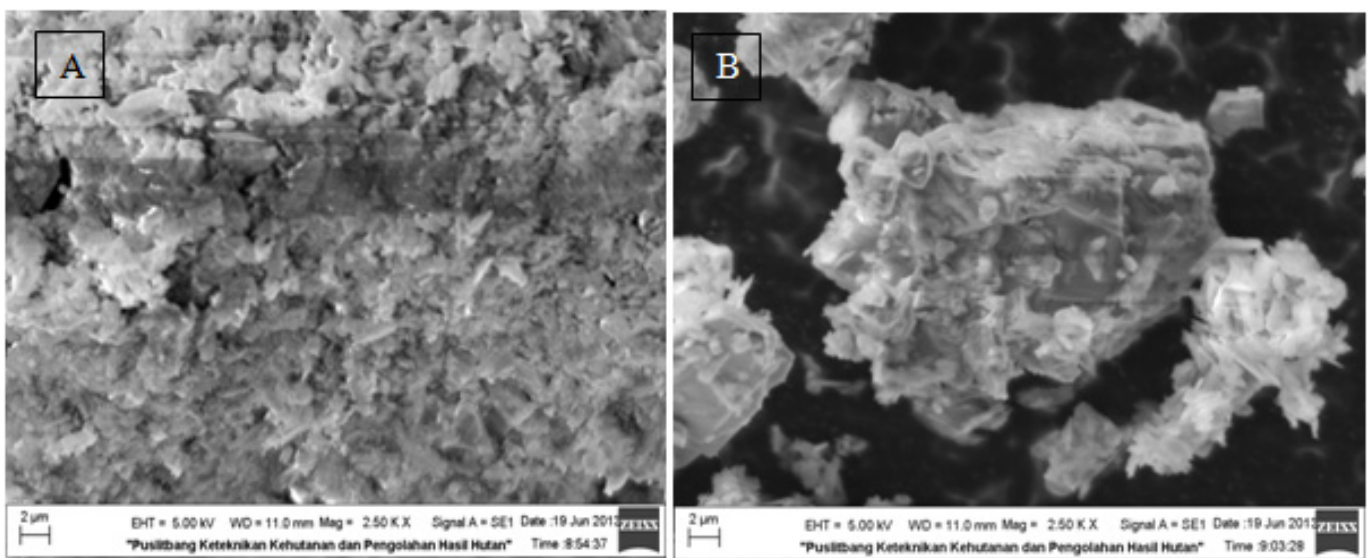

Fig 2. Photomicrograph of (A) natural zeolite and (B) HDTMABr modified zeolite

be better.

\section{Critical Admicelle Concentration (CAC) of Zeolite}

Zeolite has a net negative charge. Natural clinoptilolite has cavity dimension about 4.2-7 $\AA$ [32]. The diameter of carbohydrate chain of hexadecylammonium cation is $4 \AA$, the length is $23 \AA$, and the diameter of polar head $-\mathrm{N}^{+}\left(\mathrm{CH}_{3}\right)_{3}$ is $6.94 \AA$ which makes it too large to penetrate the largest channels in the clinoptilolite structure. Since it is the long hydrocarbon chain, it does not enter the channels in the clinoptilolite structure. Considering that $\mathrm{HDTMABr}$ is fastened to the active zeolite surface by its exchangeable complex $(\mathrm{Na}, \mathrm{Ca}, \mathrm{K}, \mathrm{Mg})$ the occupied area is equal to $102 \mathrm{~m}^{2} / 1 \mathrm{~g}$ of the zeolite. Taking into account their size HDTMA cations may be immobilized only in meso and macropores on the clinoptilolite microcrystal surface. Diffusion of HDTMA cations into micropores is out of questions because of sizes of the clinoptilolite micropores $(0.3 \mathrm{~nm} \times 0.76 \mathrm{~nm}, 0.33 \mathrm{~nm} \times$ $0.46 \mathrm{~nm}$, and $0.26 \mathrm{~nm} \times 0.47 \mathrm{~nm}$ ) [33].

Result shows that amount of HDTMA cations adsorbed onto zeolite surface were increased 10 times $(0.19-1.99 \mathrm{mmol} / \mathrm{g})$ in the range $10-100 \mathrm{mM}$ of HDTMABr. This may be due to formation of single layer (hemicelle) on the surface of Lampung zeolite. While the concentration of $\mathrm{HDTMABr}$ adsorbed was increased two fold (1.99-3.99 mmol/g) from $100-200 \mathrm{mM}$, the amount of HDTMABr adsorbed onto zeolite was also became two times. So it can be expected that in this concentration range, $\mathrm{HDTMABr}$ is starting to develop a double layer (admicelle). Nevertheless, it was decided not to raise the concentration of HDTMABr above 200 $\mathrm{mM}$ caused Wibowo [32] reported that CAC of Lampung clinoptilolite zeolite was $70 \mathrm{mM}$ with adsorption capacity (Q) $0.1967 \mathrm{mmol} / \mathrm{g}$.

\section{Sorption of $\mathrm{Cr}(\mathrm{VI})$ onto Natural and HDTMABr Modified Zeolite}

The bilayer of HDTMABr surfactant on zeolite surface provide positiviely charge sites of $-\mathrm{N}^{+}\left(\mathrm{CH}_{3}\right)_{3}$ groups which are presented to the surrounding solution and are balanced by counterions. The sorption of exchange of other anion involves the replacement of the weakly held counterions by more held counterions, such as $\mathrm{Br}^{-}$replacement with chromate. Fig. 1 shows maximum adsorption of chromate on natural zeolite about $58.05 \mathrm{mg} / \mathrm{g}$ zeolite with initial concentration of $\mathrm{Cr}(\mathrm{VI})$ was $80 \mathrm{mM}$. While the concentration of HDTMABr was increased to $200 \mathrm{mM}$ to modify zeolite surface also an increasing in the adsorption capacity of $\mathrm{Cr}(\mathrm{VI})$ equal to $148.56 \mathrm{mg} / \mathrm{g}$ zeolite. Thus, in this 


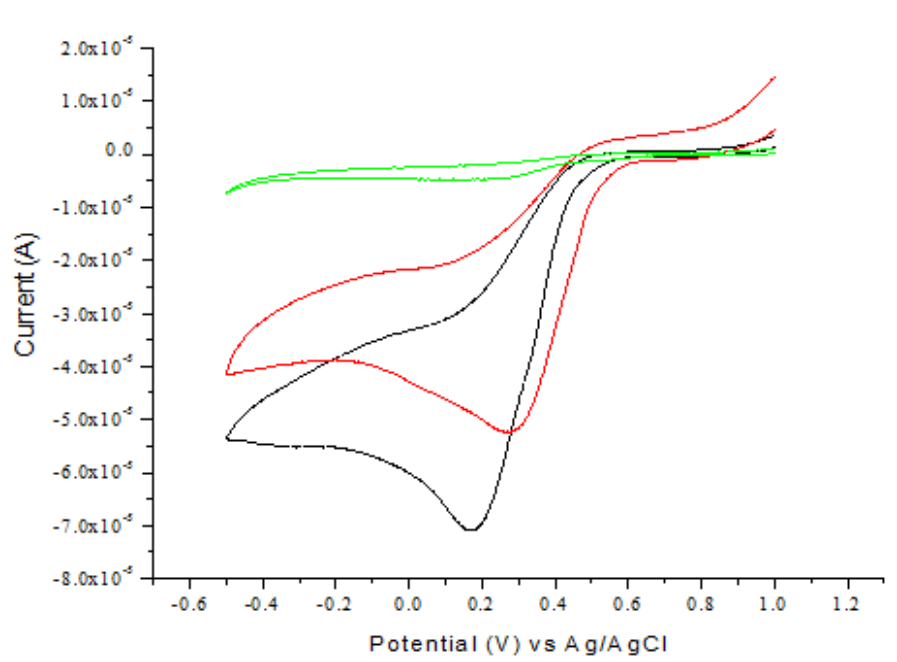

Fig 3. Cyclic voltammogram of $13 \mathrm{mM} \mathrm{Cr}(\mathrm{VI})$ in $\mathrm{HNO}_{3}$ $0.3 \mathrm{M}$ using CPE $(-)$, SMZ-CPE $(-)$, and gold electrode $(-)$

experiment was selected $200 \mathrm{mM}$ HDTMABr modified zeolite which has the highest adsorption of $\mathrm{Cr}(\mathrm{VI})$.

\section{Characterization of Zeolite with SEM}

The surface of natural zeolite and HDTMABr modified zeolite were observed by using a SEM. This analysis revealed information about the details of the surface and morphology of the particles. Fig. 2 (A) presents natural zeolite image that displays partially developed crystalline laminar habits and conglomerates of compact crystals. In addition, crystals with a tabular habit which is typical of clinoptilolite are observed as well as the presence of a large variety and particle sizes. Fig. 2 (B) shows an image of the SMZ and the laminar crystals observed in natural zeolite cannot be seen clearly. This is because the surfactant was adsorbed on the external surface of the zeolite crystals and also possibility of formation the surfactant admicelles coating.

\section{Optimization of the Electrode Composition}

In the present work, voltammetric responses for SMZ-CPE prepared from HDTMABr modified zeolite and graphite mixtures, different ratios, were examined by cyclic voltammetric under identical conditions. Result shows measurement of $13 \mathrm{mM} \mathrm{Cr}(\mathrm{VI})$ using SMZ-CPE as working electrode by cyclic voltammetry technique with the highest response observed from $2.5 \% \mathrm{w} / \mathrm{w}$ ratio with peak current was $41.20 \mu \mathrm{A}$ compared with another ratios $(\mathrm{w} / \mathrm{w}) 1 \%(35.83 \mu \mathrm{A}), 5 \%(33.13 \mu \mathrm{A}), 7.5 \%(26.83$ $\mu \mathrm{A})$, and $10 \%(25.93 \mu \mathrm{A})$. The best sensitivity, reproducibility and mechanical stability were obtained with the amount of $2.5 \mathrm{mg}$ of HDTMABr modified zeolite.

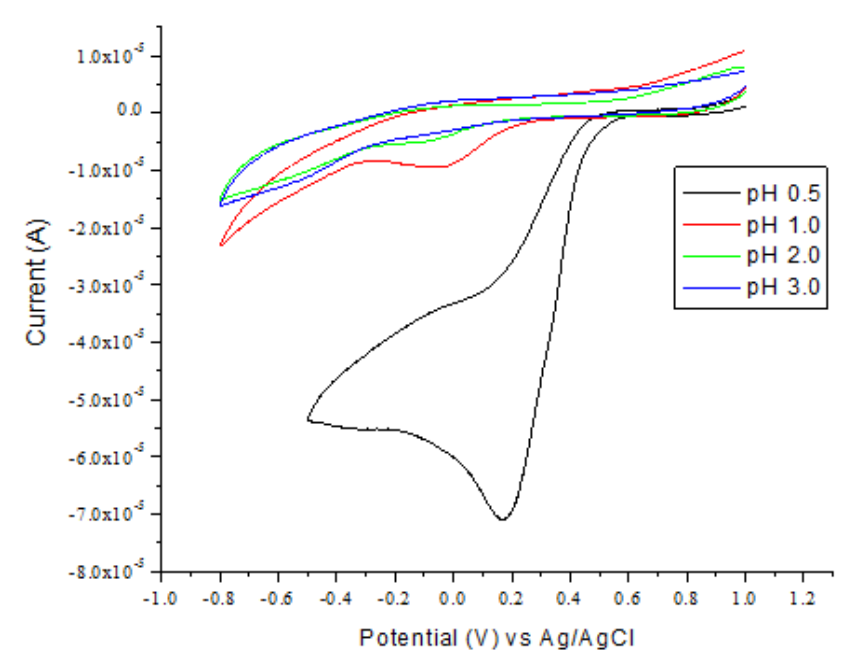

Fig 4. Cyclic voltammogram for reduction $13 \mathrm{mM}$ at $\mathrm{pH}$ values of $0.5,1,2$, and 3 on SMZ-CPE and with scan rate $100 \mathrm{mV} / \mathrm{s}$

Hence, a quantity of $2.5 \mathrm{mg}$ was chosen as optimum amount of natural zeolite.

The effectiveness of HDTMABr modified zeolite in the detection of $\mathrm{Cr}(\mathrm{VI})$ was investigated voltammetrically using solution containing $\mathrm{Cr}(\mathrm{VI})$ by comparing carbon paste electrode, gold electrode versus SMZ-CPE as working electrode. As depicted in Fig. 3, the gold electrode showed the lowest sensitivity towards the reduction of $\mathrm{Cr}(\mathrm{VI})$ which resulted small voltammetric signal in the potential range of 0.0-0.4 V (versus $\mathrm{Ag} / \mathrm{AgCl}$ ). In contrast the SMZ-CPE shows higher sensitivity than $\mathrm{CPE}$ for $\mathrm{Cr}(\mathrm{VI})$ reduction using cyclic voltammetry in a well defined peak with a peak potential of $0.2 \mathrm{~V}$. There was no need for oxygen purging using the proposes method since $\mathrm{Cr}(\mathrm{VI})$ peak appears at potentials more positive than the oxygen peak and hence no interference was neither expected during experiments.

The effect of other parameters such as $\mathrm{pH}$ during measurement was investigated. Fig. 4 shows cyclic voltammogram for reduction of $13 \mathrm{mM} \mathrm{Cr}(\mathrm{VI})$ in adjustment $\mathrm{pH}$ to $0.5,1,2$, and 3 . As can be seen in Fig. 4, the reduction of $\mathrm{Cr}(\mathrm{VI})$ in $\mathrm{pH} 0.5$ results in a sharp and well defined peak, while increasing the $\mathrm{pH}$ 0.5 to 1 reduces peak size quite significantly, while further increase to pHs 2 and 3 results effective disappearance of the reduction peak. This experiment demonstrates that the $\mathrm{pH}$ of the supporting electrolyte has a profound effect on the sensitivity, size and the shape of the chromium reduction peak on the SMZ-CPE. It is evident that a highly acidic solution is required for the analytically successful reduction of chromium and presence of a high concentration of protons $\left(\mathrm{H}^{+}\right)$is essential for the progress of this 


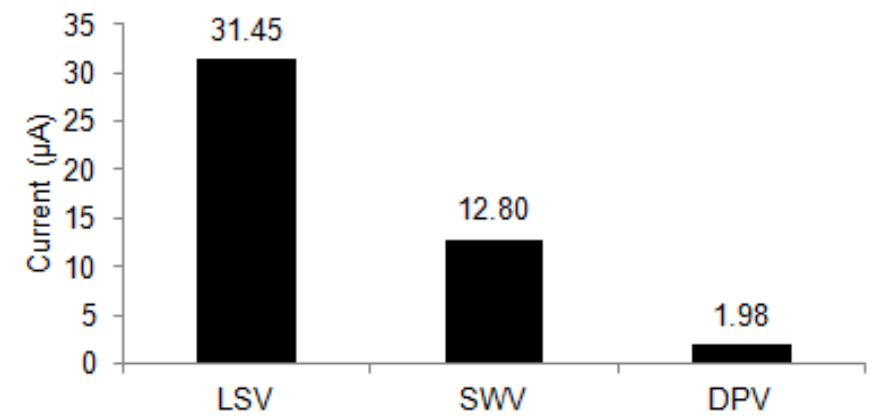

Fig 5. Measurement of $13 \mathrm{mM} \mathrm{Cr}(\mathrm{VI})$ using 3 different voltammetry techniques: linear swwp voltammetry (LSV), square wave voltammetry (SWV), and differential pulse voltammetry (DPV) on SMZ-CPE with scan rate 100 $\mathrm{mV} / \mathrm{s}$

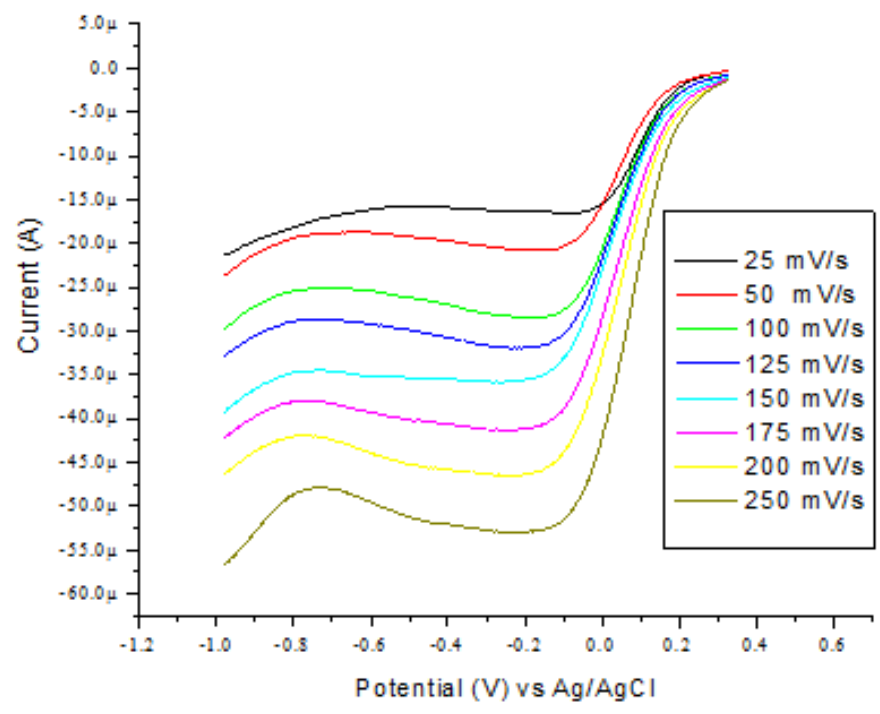

Fig 6. Linear sweep voltammetric signal of $5 \mathrm{mM} \mathrm{Cr}(\mathrm{VI})$ on SMZ-CPE with scan rate 25, 50, 100, 125, 150, 175, 200 , and $250 \mathrm{mV} / \mathrm{s}$ in $0.3 \mathrm{M} \mathrm{HNO}_{3}$

chromium reduction reaction. Therefore a strong inorganic acid (esp. nitric and sulfuric) at a concentration of $0.3 \mathrm{M}$ was used analytically for chromium(VI) detection [3]. However, since $\mathrm{pH} 0.5$ proved to be the optimum $\mathrm{pH}, 0.3 \mathrm{M} \mathrm{HNO}_{3}$ which also provides $\mathrm{pH}$ value of ca. 0.5 can be used as an alternative supporting electrolyte with a simpler matrix.

In the aqueous phase, chromate exists in different ionic forms $\left(\mathrm{HCrO}_{4-}, \mathrm{Cr}_{2} \mathrm{O}_{7}{ }^{2-}, \mathrm{CrO}_{4}{ }^{2-}, \mathrm{HCr}_{2} \mathrm{O}_{7}^{-}\right)$. The distribution of $\mathrm{Cr}(\mathrm{VI})$ species is dependent on both the total concentration of $\mathrm{Cr}(\mathrm{VI})$ and $\mathrm{pH}$ of the equilibrium solution. The following equations describe the distribution of chromium species in aqueous solution [34]:

$\mathrm{H}_{2} \mathrm{CrO}_{4} \rightleftharpoons \mathrm{HCrO}_{4}^{-}+\mathrm{H}^{+}\left(\mathrm{K}_{1}: 1.21\right)$

$\mathrm{HCrO}_{4}^{-} \rightleftharpoons \mathrm{H}^{+}+\mathrm{CrO}_{4}{ }^{2-}\left(\mathrm{K}_{2}: 3 \times 10^{-7}\right)$
$2 \mathrm{HCrO}_{4}^{-} \rightleftharpoons \mathrm{Cr}_{2} \mathrm{O}_{7}^{2-}+\mathrm{H}_{2} \mathrm{O}\left(\mathrm{K}_{3}: 35.5\right)$

$\mathrm{HCr}_{2} \mathrm{O}_{7}^{-} \rightleftharpoons \mathrm{H}++\mathrm{Cr}_{2} \mathrm{O}_{7}^{2-}\left(\mathrm{K}_{4}: 0.85\right)$

The $\mathrm{CrO}_{4}{ }^{2-}$ anion prevails in basic or slightly acidic solution while the $\mathrm{Cr}_{2} \mathrm{O}_{7}{ }^{2-}$ anion is dominant in acidic $\mathrm{Cr}(\mathrm{VI})$ aqueous solution $\mathrm{pH}$ aqueous [15]:

$\mathrm{CrO}_{4}{ }^{2-}(\mathrm{pH}>6.5) \rightleftharpoons \mathrm{HCrO}_{4}^{-}(\mathrm{pH} 4-6) \rightleftharpoons \mathrm{Cr}_{2} \mathrm{O}_{7}{ }^{2-}(\mathrm{pH}<4)$

Since both anionic is the predominant form of the chromium species at the conditions used in this work, the sorption mechanism can be shown by the following reaction [2]:

$\mathrm{R}_{4} \mathrm{~N}^{+}+\mathrm{HCrO}_{4}^{-} \leftrightharpoons\left[\mathrm{R}_{4} \mathrm{~N}^{+}\right] \mathrm{HCrO}_{4}^{-}$

$2 \mathrm{R}_{4} \mathrm{~N}^{+}+\mathrm{Cr}_{2} \mathrm{O}_{7}^{2-}=\left[\mathrm{R}_{4} \mathrm{~N}^{+}\right]_{2} \mathrm{Cr}_{2} \mathrm{O}_{7}^{-}$

Where, $\mathrm{R}_{4} \mathrm{~N}^{+}$represents the anion-exchange sites of HDTMA surfactant on SMZ. Thus, when the SMZ-CPE is immersed in the chromate solutions, an anion exchange reaction occurs between the anion on the electrode surface $\left(\mathrm{Br}^{-}\right)$and $\mathrm{CrO}_{4}{ }^{2-}$ in the solution [15].

\section{Optimization of Simple Voltammetry Technique}

Square wave voltammetry (SWV), differential pulse voltammetry (DPV) and linear sweep voltammetry (LSV) methods without any deposition or accumulation stage were compared. Fig. 5 shows value of peak current which is obtained from 3 different voltammetry techniques for $13 \mathrm{mM} \quad \mathrm{Cr}(\mathrm{VI})$ measurements in a $0.3 \mathrm{M} \mathrm{HNO}_{3}$ on SMZ-CPE. As can be seen in Fig. $5 \mathrm{LSV}$ method has the greatest sensitivity and also more stability for the measurement of $\mathrm{Cr}(\mathrm{VI})$, in terms of peak shape, peak size and peak position. Therefore, the linear sweep voltammetry technique was adopted as the techniques of choice for the detection of chromium(VI) throughout this study.

The effect of scan rate on the reduction peak of $\mathrm{Cr}(\mathrm{VI})$ in solution of $5 \mathrm{mM}$ chromate in $0.3 \mathrm{M} \mathrm{HNO}_{3}$ was investigated from 25 to $250 \mathrm{mV} / \mathrm{s}$ (Fig. 6), and there is linear relationship was achieved between the current and the scan rate or square root of scan rate which suggests that the mass transfer of $\mathrm{Cr}(\mathrm{VI})$ ions is under combined control of diffusion and adsorption. The peak current $\left(I_{p}\right)$ versus the square root of scan rate $\left(V^{1 / 2}\right)$ was also obtained and it showed linear regression as followed:

$I_{p c}$ SMZ-CPE $=1.8812 V^{1 / 2}-0.6066 \quad R^{2}=0.9406$

which is expected for a diffusion controlled system. A scan rate $100 \mathrm{mV} / \mathrm{s}$ was selected as a compromise between the reduction peak sensitivity and peak shape.

\section{Analytical Characteristics}

The linear range for $\mathrm{Cr}(\mathrm{VI})$ measurement was evaluated 6 replicates. The peak current increased linearly with $\mathrm{Cr}(\mathrm{VI})$ concentration over $0.2 \mathrm{mM}-1.0$ $\mathrm{mM}\left(r^{2}=0.9669\right)$ with scan rate $150 \mathrm{mV} / \mathrm{s}$. Sensitivity, 
detection and quantification limit for $\mathrm{Cr}(\mathrm{VI})$ measurement using this type electrode was found $0.4294 \mathrm{mM}, 3.63 \mathrm{x}$ $10^{-4} \mathrm{mM}$, and $1.197 \times 10^{-3} \mathrm{mM}$, respectively. Precision was found to be $4.46 \%$ from $1 \mathrm{mM} \mathrm{Cr}(\mathrm{VI})$ measurements with 10 replicates.

\section{CONCLUSION}

We here report for the first time the use of HDTMABr modified zeolite carbon paste electrode for the voltammetric determination of $\mathrm{Cr}(\mathrm{VI})$. SMZ-CPE has optimum composition was $2.5 \%, 0.3 \mathrm{M} \mathrm{HNO}_{3}$ electrolyte solution with $\mathrm{pH} 0.5$ by cyclic voltammetry technique. Performance of testing electrode using linear sweep voltammetry technique showed linear response in concentration range $0.2-1.0 \mathrm{mM}$ with coefficient of determination $\left(r^{2}\right)$ of 0.9669 , limit of detection and quantitation, and precision was $3.63 \times 10^{-4} \mathrm{M}, 1.197 \mathrm{x}$ $10^{-3} \mathrm{M}$, and $4.49 \% \% \mathrm{RSD}$, respectively.

\section{REFERENCES}

1. Gómez, V., and Callao, M.P., 2006, TrAC, Trends Anal. Chem., 25, 10, 1006-1015.

2. Švancara, I., Foret, P., and Vytřas, K., 2004, Talanta, 64, 4, 844-852.

3. Kachoosangi, R.T., and Compton, R.G., 2013, Sens. Actuator, B, 178, 555-562.

4. Cespón-Romero, R.M., Yebra-Biurrun, M.C., and Bermejo-Barrera, M.P., 1996, Anal. Chim. Acta, 327, 1, 37-45.

5. Ndung'u, K., Djane, N-K., Malcus, F., and Mathiasson, L., 1999, Analyst, 124, 1367-1372.

6. Sumida, T., Ikenoue, T., Hamada, K., Sabarudin, A., Oshima, M., and Motomizu, S., 2005, Talanta, 68, 2, 388-393.

7. Saygi, K.O., Tuzen, M., and Soylak, M., 2008, J. Hazard. Mater., 153, 3, 1009-1014.

8. Cathum, S., Brown, C.E., and Wong, W., 2002, Anal. Bioanal. Chem., 373, 1-2, 103-110.

9. Parsons, J.G., Dokken, K., Peralta-Videa, J.R., Romero-Gonzalez, J., and Gardea-Torresdey, J.L., 2007, Appl. Spectrosc., 61, 3, 338-345.

10. Cleveland, D., Peter, S., Hou, X., Yang, K.X., Zhou, J., and Michel, R.G., 2005, Appl. Spectrosc., 59, 12, 1427-1444.

11. Xing, S., Xu, H., Shi, G., Chen, J., Zeng, L., and Jin, L., 2009, Electroanalysis, 21, 15, 1678-1684.

12. Wang, J., Wang, J., Lu, J., Tian, B., MacDonald, D., and Olsen, K., 1999, Analyst, 124, 349-352.
13. Burke, L.D., and Nugent, P.F., 1997, Electrochim. Acta, 42, 3, 399-411.

14. Welch, C.M., Nekrassova, O., and Compton, R.G., 2005, Talanta, 65, 1, 74-80.

15. Nezamzadeh-Ejhieh, A., and Raja, G., 2013, J. Chem., 2013, 1-13, DOI: 10.1155/2013/68290.

16. Li, Z., and Bowman, R.S., 1997, Environ. Sci. Technol., 31, 8, 2407-2412.

17. Xu, S., and Boyd, S.A., 1995, Langmuir, 11, 7 , 2508-2514.

18. Haggerty, G.H., and Bowman, R.S., 1994, Environ. Sci. Technol., 28, 3, 452-458.

19. Švancara, I., Vytřas, K., Kalcher, K., Walcarius, A., and Wang, J., 2009, Electroanalysis, 21, 1, 7-28.

20. Wang, J., and Walcarius, A., 1996, J. Electroanal. Chem., 407, 1-2, 183-187.

21. Walcarius, A., Mariaulle, P., and Lamberts, L., 2003, J. Solid State Electrochem., 7, 671-677.

22. Nezamzadeh-Ejhieh, A., and Masoudipour, N., 2010, Anal. Chim. Acta, 658, 68-74.

23. Walcarius, A., 1998, Electroanalysis, 8, 11, 971986.

24. Klute, A., 1986. Method of Soil Analysis Part 1: Physical and Mineralogical Methods, $2^{\text {nd }}$ ed., US of Agronomy of Soil Science Society of America, Wisconsin.

25. Nezamzadeh-Ejhieh, A., and Esmaeilian, A., 2012, Microporous Mesoporous Mater., 147, 302-309.

26. Wibowo, W., Utari, T., and Yuniarti, R.T., 2011, Makara, 15, 1, 53-57.

27. Inglezakis, V.J., Papadeas, C.D., Loizidou, M.D., and Grigoropoulou, H.P., 2001, Environ. Technol., 22, 1, 75-82.

28. Ackley, M.W., Rege, S.U., and Saxena, H., 2003, Microporous Mesoporous Mater., 61, 25-45.

29. Ates, A., and Hardacre, C., 2012, J. Colloid Interface Sci., 372, 1, 130-140.

30. Jozefaciuk, G., and Bowanko, G., 2002, Clays Clay Miner., 50, 6, 771-783.

31. Bonenfant, D., Kharoune, M., Niquette, P., Mimeault, M., and Hausler, R., 2008, Sci. Technol. Adv. Mater., 9, 1-7.

32. Wibowo, W., Utari, T., and Yunarti, R.T., 2011, Makara, 15, 1, 53-57.

33. Sprynskyy, M., Ligor, T., Lebedynets, M., and Buszewski, B., 2009, J. Hazard. Mater., 169, 1-3, 847-854.

34. Kabay, N., Arda, M., Saha, B., and Streat, M., 2003, React. Funct. Polym., 54, 1-3, 103-115. 